\title{
Adiponectin and Endometrial Cancer: A Systematic Review and Meta-Analysis
}

\author{
Fangxin Zenga,b Jinyu Shib Yang Long ${ }^{\mathrm{c}}$ Haoming Tian ${ }^{\mathrm{b}}$ Xiaoxi Li $^{\mathrm{d}}$ \\ Allan Z. Zhao ${ }^{d}$ Rose Fanghong Lid,e Tao Chen ${ }^{b}$
}

\begin{abstract}
aDepartment of Endocrinology, Dazhou Integrated Traditional Chinese and Western Medicine Hospital, Dazhou, 'Department of Endocrinology and Metabolism, West China Hospital of Sichuan University, Chengdu, 'Laboratory of Endocrinology and Metabolism, West China Hospital of Sichuan University, Chengdu, 'The Center of Metabolic Disease Research, State Key Laboratory of Reproductive Medicine, Nanjing Medical University, Nanjing, eDepartment of Pathology, State Key Laboratory of Reproductive Medicine, Department of Pathology, The First Affiliated Hospital, Nanjing Medical University, Nanjing, P. R. China
\end{abstract}

\section{Key Words}

Endometrial cancer - Obesity-related cancer - Adiponectin - Adipokines - Postmenopausal women

\begin{abstract}
Objective: This study evaluates the association between serum adiponectin concentrations and the risk of endometrial cancer through a comprehensive meta-analysis of currently available clinical data. Methods: PubMed, Embase, the Chinese Biomedical Literature Database and the Science Citation Index (ISI Web of Science) were searched for studies that examined the association between blood adiponectin concentrations and the risk of endometrial cancer. Data from studies that met the inclusion criteria were systematically reviewed, and pooled analyses were performed according to the guidelines of Meta-Analysis of Observational Studies in Epidemiology and PRIMSA. Results: Eight case-control studies (including 1257 endometrial cancer patients and 2008 controls) and four nested case-control studies (including 659 endometrial cancer patients and 1398 controls) were included. We found that serum adiponectin level was inversely correlated with the risk of endometrial cancer development after pooling the case-control studies (OR $=0.50,95 \%$ CI: 0.39-0.60; $P<0.001)$. However, meta-analysis of nested case-control studies thus far did not support a broad linkage between serum adiponectin level and endometrial cancer, although a correlation may exist in the subgroup of postmenopausal women (OR=0.81,95\%CI: $0.65-1.00 ; P=0.060)$, particularly in postmenopausal women without current hormone replacement therapy $(\mathrm{OR}=0.62,95 \%$ CI: 0.44-0.86; $P=0.004)$. Conclusions: Meta-analysis of currently available clinical evidence supports the association between high serum adiponectin concentration and reduced risk of endometrial cancer development, particularly in the group of postmenopausal women without current hormone replacement therapy. However, additional studies with prospective design are required to fully support this linkage.
\end{abstract}

Copyright $(2015$ S. Karger AG, Basel

Tao Chen, M.D.

and Fanghong Li, M.D.

KARGER 125
Dept Endocrinol and Metabol West China Hospital, Sichuan University 37 Guoxue Street, Chengdu, Sichuan 610041 (P. R. China) and State Key Lab Reproduct Med, Dept Pathology, The First Affiliated Hospital, Nanjing Medical University, Nanjing, Jiangsu 210029 (P. R. China); E-Mail dr.chentao@gmail.com and E-Mail fli@njmu.edu.cn 


\section{Cellular Physiology Cell Physiol Biochem 2015;36:1670-1678 \begin{tabular}{l|l} 
DOI: 10.1159/000430327 & (c) 2015 S. Karger AG, Basel
\end{tabular} \begin{tabular}{l|l} 
and Biochemistry Published online: July 10, 2015 & www.karger.com/cpb
\end{tabular} \\ Zeng et al.: Adiponectin and Endometrial Cancer}

\section{Introduction}

Obesity is known to increase the risks of certain types of cancers. Among which, obesity may account for $17-46 \%$ of the increased risk of endometrial cancer in postmenopausal women [1]. The mechanisms underlying such associations can be multitudes, which entail insulin resistance, chronic inflammation, and alterations in the concentrations of circulating adipokines [2-5].

Among all adipokines, adiponectin is the most abundant one in blood. Despite the fact that it is primarily produced in adipose tissue, serum concentrations of adiponectin are paradoxically reduced in obese patients [6]. Besides its intimate involvement in the regulation of metabolism, adiponectin has been shown in a series of in vitro studies that inhibits the proliferation of several cancer-derived cell-types such as breast cancer, endometrial cancer, prostate cancer and colorectal cancer [7-15]. The suppressive effects on these cancers may involve AMPK-mediated or non-AMPK-mediated modulation of mTOR-S6K, PI3K-AKT, JUNSTAT3 and MAPK signaling pathways, suggesting that adiponectin may play a direct role in tumor development and growth [3,16-18].

Consistent with these in vitro observations, the results from some emerging epidemiological studies have shown that low levels of adiponectin are correlated with elevated risks of breast cancer [19], colon cancer [19, 20] and prostate cancer [19]. In 2003, Petridou et al. reported that plasma adiponectin concentration was inversely related to the risk of endometrial cancer [21]. Since then, other case-control or nested case-control studies have been published with occasional conflicting results [21-32]. The goal of this study is to further clarify the relationship between blood adiponectin and endometrial cancer. To this end, all currently available clinical studies in this area were comprehensively analyzed using meta-analysis, following the guidelines given in Meta-Analysis of Observational Studies in Epidemiology (MOOSE) and Preferred Reporting Items for Systematic Reviews and MetaAnalyses (PRISMA).

\section{Materials and Methods}

\section{Search strategy}

The databases of Medline (PubMed), Embase (Embase.com), the Science Citation Index (ISI Web of Science) and the Chinese Biomedical Literature Database (CBM via the Electronic Library of Sichuan University) were electronically searched to obtain all publications related to the association between adiponectin and endometrial cancer (up to September 1, 2014) without language restriction. "Adiponectin" and "Endometrial Neoplasms" and their related terms were used. To avoid missing any relevant studies, reference lists from highly related reviews were further retrieved. For studies published in languages other than English and Chinese, a foreign language teacher or a language translation company was consulted. Studies were compared to eliminate reports that potentially duplicated the results of the same patients, and when necessary, the authors were contacted.

\section{Study selection}

Studies were included if they satisfied the following criteria: 1) Reference levels (e.g. the lowest category of tertiles, quartiles or quintiles) and at-risk levels of adiponectin (e.g. the highest category of tertiles, quartiles or quintiles) were provided. 2) endometrial cancer was the outcome of interest; 3) estimate effect, such as hazard ratio (HR), relative risk (RR) or odds ratio (OR) with $95 \%$ confidence interval (CI), was provided.

Data extraction and assessment of quality

Two authors (Zeng, Fangxin and Chen, Tao) independently extracted information from the studies, and any disagreements were resolved through discussion to achieve consensus. The following data were extracted for each of the studies that met the selection criteria: the name of the first author, the year of publication, the country of origin of study, ethnicity, mean age and age range, the amounts of all participants 


\begin{tabular}{|c|c|c|}
\hline Cellular Physiology & Cell Physiol Biochem 2015;36:1670-1678 & \\
\hline and Biochemistry & $\begin{array}{l}\text { DOI: 10.1159/000430327 } \\
\text { Published online: July 10, } 2015\end{array}$ & $\begin{array}{l}\text { O } 2015 \text { S. Karger AG, Basel } \\
\text { www.karger.com/cpb }\end{array}$ \\
\hline
\end{tabular}

and endometrial cancer cases, the fully adjusted effect-estimates with the corresponding 95\% CIs and study-specific adjusted confounding factors. The quality of included studies was evaluated according to the Newcastle-Ottawa scale (Table 4)[33].

\section{Statistical analysis}

OR with $95 \% \mathrm{CI}$ was chosen as the effect-estimate to assess the potential association between serum adiponectin and endometrial cancer. One study presented data in the form of $R R$, and it was deemed equivalent to OR for pooled analysis. We calculated the combined ORs with $95 \%$ CIs by comparing the highest category versus the lowest category of adiponectin levels and using the most adjusted effects-estimates. Due to the included studies had different cut-off values or different categories of adiponectin (e.g. tertiles or quartiles), which could lead to heterogeneity and weaken the pooled results, the present study further calculated the estimated effects and $95 \%$ CIs for an increment of $10 \mu \mathrm{g} / \mathrm{ml}$ of adiponectin with studies divided the levels of adiponectin into more than two categories (e. g. tertiles, quartiles, etc.). This dose-response analysis was performed according to the method provided by Greenland, Orsini and colleagues [34, 35].

Heterogeneity among studies was examined with the chi-square-based $Q$-test and the $I^{2}$-test. In doseresponse analysis, heterogeneity was assessed by goodness of fit test [35]. When significant heterogeneity ( $P$-value $<0.05$ and $I>50 \%$ ) was detected, the pooled OR and 95\% CI were estimated with a randomeffect model; otherwise, a fixed-effect model was used. Subgroup analyses were further carried out by study location, menopausal status (pre- or postmenopausal women), and postmenopausal hormone replace treatment. For the purpose of concision, only dose-response analysis was performed in subgroup analyses.

Sensitivity analysis was conducted to evaluate the influence of each individual study on the pooled results. Any potential publication biases were determined using Begg's and Egger's tests. All statistical analyses were conducted with Stata software, version 12.0 (Stata Corp, College Station, Texas, USA). A $P$-value less than 0.05 was considered to be statistically significant.

\section{Results}

\section{Literature research}

A diagram of the literature search was shown in Figure 1. Initially, 310 potentially relevant articles were identified; 289 of these were excluded based on the titles and abstracts. The full texts of the remaining 21 articles were reviewed. Nine studies were excluded for the following reasons: six studies did not calculate their data on effects-estimates (i.e. HR, RR or OR); two were review studies; one study did not provide data about the effect on endometrial cancer. Finally, 12 articles were included in this study [21-32].

\section{Study characteristics}

This study included four nested casecontrol studies involving 659 endometrial cancer patients and 1398 controls [25-28]. In addition, there were eight case-control studies involving 1257 endometrial cancer patients and 2008 controls [21-24, 29-32]. These studies were published between 2003 and 2013. Four studies were from Europe, five from America, and three from Asia. One of the case-control studies [31] showed sharply different levels of adiponectin which were dozens of times lower than those of other studies. Another one [21] only analyzed the association between per one standard deviation or per one quintile increase of adiponectin and endometrial cancer risk. We contacted the author of this paper but failed
Fig. 1. A flow diagram of the literature search.

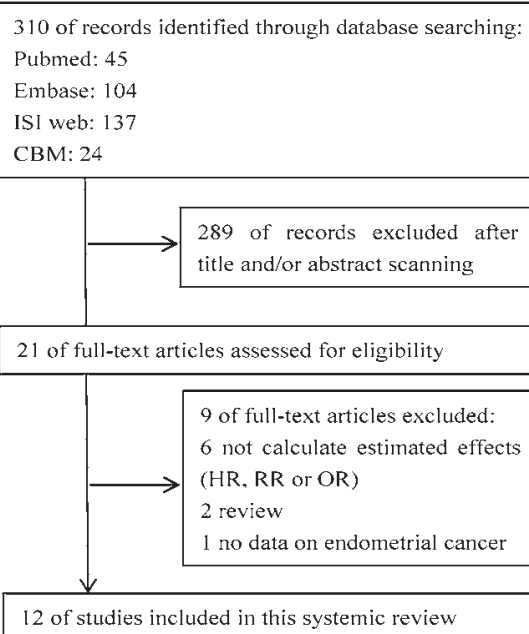

1 2 of studies included in this systemic review 




Table 1. General character of studies included in this study. Note: NR = not reported. * Factors were described as percent in different categories not as Mean \pm SD or Median (Inter-Quartile Range)

\begin{tabular}{|c|c|c|c|c|c|c|}
\hline Study ID & Design & $\begin{array}{l}\text { Country } \\
\text { /Region }\end{array}$ & Race(\%) & $\begin{array}{l}\text { Sample size } \\
\text { Case/controls }\end{array}$ & $\begin{array}{l}\text { Age (years)* } \\
\text { Case/controls }\end{array}$ & $\begin{array}{l}\text { BMI }\left(\mathrm{kg} / \mathrm{m}^{2}\right)^{*} \\
\text { Case } / \text { controls }\end{array}$ \\
\hline $\operatorname{Ma} Y(2013)[22]$ & Case-control & China & Asian & $206 / 310$ & $53.2(26-81) / 53.3(27-82)$ & NR \\
\hline Ohbuchi Y (2013)[23] & Case-control & Japan & Asian & $43 / 62$ & $61.2 \pm 9.8 / 58.1 \pm 8.3$ & $26.1 \pm 4.5 / 23.3 \pm 3.8$ \\
\hline Erdogan S (2013)[24] & Case-control & Turkey & NR & $60 / 70$ & $56.6 \pm 9.1 / 49.7 \pm 7.6$ & $31.1 \pm 4.2 / 27.5 \pm 3.2$ \\
\hline $\begin{array}{l}\text { Friedenreich } \\
\text { CM(2012)[29] }\end{array}$ & Case-control & Canada & NR & $514 / 962$ & $59(, 53,65) / 59(52,66)$ & $31.0(26.4,36.8) / 27.2(24.1,30.9)$ \\
\hline Ashizawa N.(2010)[30] & Case-control & Japan & Asian & $146 / 150$ & $59.9 / 57.5$ & $23.7 \pm 4.6 / 22.0 \pm 3.3$ \\
\hline Soliman PT (2006)[31] & Case-control & US & Caucasian (83.4\%) & $117 / 238$ & $66.6(25-88) / 61.2(50-80)$ & $33.2 / 28.0$ \\
\hline Dal Maso L(2004)[32] & Case-control & Italy & NR & $87 / 132$ & $62 / 61$ & $\begin{array}{l}<25: 23 / 45 ; 25-30: 39 / 42 ; \\
\geq 30: 38 / 12^{*}\end{array}$ \\
\hline Petridou E (2003[21] & Case-control & Greece & NR & $84 / 84$ & $\begin{array}{l}<55: 20.2 / 20.2 ; 55-64: 32.1 / 26.2 \\
65-74: 36.9 / 42.9 ; 74+: \\
10.7 / 10.7^{*}\end{array}$ & $\begin{array}{l}<25: 20.2 / 29.8 ; 25-26: 15.5 / 36.9 \\
26-28: 21.4 / 10.7 ; 29-30: \\
15.5 / 11.9 \\
\geq 31: 27.4 / 10.7^{*}\end{array}$ \\
\hline Luhn P (2013)[25] & $\begin{array}{l}\text { Nested case- } \\
\text { control }\end{array}$ & US & $\begin{array}{l}\text { White non-Hispanic } \\
\text { (94.3) } \\
\text { Black non-Hispanic(2.6) } \\
\text { Asian(3.1) }\end{array}$ & $167 / 327$ & $\begin{array}{l}<60: 25.8 / 26.3 ; 60-64: 35.3 / 35 \\
65-69: 28.7 / 28.1 ; 70+: \\
10.2 / 10.4^{*}\end{array}$ & $\begin{array}{l}<25: 27.5 / 43.4 ; 25-30: 33.5 / \\
31.8 \\
30-35: 17.4 / 18.0 ; 35+: 21.6 / 6.7^{*}\end{array}$ \\
\hline Dallal CM (2013)[26] & $\begin{array}{l}\text { Nested case- } \\
\text { control }\end{array}$ & US & Caucasian & $62 / 124$ & $67.4 \pm 5.5 / 67.5 \pm 5.1$ & $29.5 \pm 6.9 / 26.8 \pm 4.7$ \\
\hline Soliman PT(2011)[27] & $\begin{array}{l}\text { Nested case- } \\
\text { control }\end{array}$ & US & Caucasian (99\%) & $146 / 399$ & $57(47-67) / 57(47-67)$ & $27.2 / 25.5$ \\
\hline Cust AE(2007)[28] & $\begin{array}{l}\text { Nested case- } \\
\text { control }\end{array}$ & Europe & NR & $284 / 548$ & $\begin{array}{l}56.9(45.4-67.9) / 56.9(45.0- \\
68.0)\end{array}$ & $28.1(20.9-37.6) / 26.5(20.2-34.8)$ \\
\hline
\end{tabular}

Table 2. Data obtained from included studies. * T3 the third tertile, T1 the first tertile, Q4 the fourth quartile, Q1 the first quartile; $\Delta$ measured both total and multimers of adiponectin. Abbreviations: BMI Body mass index; HRT hormone replacement therapy; IGF insulin-like growth factor; IGFBP IGF binding protein; OR odds ratio; QUICKI quantitative insulin sensitivity check index; SHBG sex hormone binding globulin

\begin{tabular}{|c|c|c|c|c|c|c|}
\hline Study ID & $\begin{array}{l}\text { Adiponectin }(\mu \mathrm{g} / \mathrm{ml}) \\
\text { Case/control }\end{array}$ & $\begin{array}{l}\text { Adiponectin } \\
\text { Assays }\end{array}$ & $\begin{array}{l}\text { Risk } \\
\text { definition* }\end{array}$ & $\begin{array}{l}\text { Estimate } \\
\text { Effects }\end{array}$ & Values $(95 \% \mathrm{CI})$ & Adjusted confounding factors \\
\hline \multicolumn{7}{|l|}{ Case-control studies } \\
\hline $\operatorname{MaY}(2013)[22]$ & $2.3 \pm 0.2 / 2.6 \pm 0.1$ & ELISA & $\mathrm{T} 3$ vs. T1 & $O R$ & $0.52(0.32,0.83)$ & $\begin{array}{l}\text { Age, BMI, glucose,TC, TG, HDL-c, insulin and leptin-to- } \\
\text { adiponectin }\end{array}$ \\
\hline Ohbuchi Y (2013)[23] & $4.9(1.6,13.5) / 7.0(2.9,26.1)$ & ELISA ${ }^{\triangle}$ & $\begin{array}{l}\text { Quantile } 2 \text { vs } \\
\text { quantile } 1\end{array}$ & OR & $0.503(0.073,3.448)$ & $\begin{array}{l}\text { Age, BMI, hypertension, and diabetes } \\
\text { mellitus }\end{array}$ \\
\hline Erdogan S (2013)[24] & $4.1(0.7-43.6) / 17.1(2.6,108.7)$ & ELISA & T1 vs. T3 & OR & $10.80(2.76,42.24)$ & Age, BMI, HOMA-IR and QUICKI \\
\hline FriedenreichCM(2012)[29] & $11.6(7.7,17.3) / 14.6(10.0,21.5)$ & ELISA & Q4 vs. Q1 & $\mathrm{OR}$ & $0.55(0.37,0.80)$ & $\begin{array}{l}\text { Age, parity, HRT, hypertension, weight, WHR, glucose, } \\
\text { leptin, insulin. }\end{array}$ \\
\hline Ashizawa N.(2010)[30] & $6.2 \pm 04 / 9.0 \pm 0.4$ & ELISA & T3 vs. T1 & OR & $0.6(0.3,1.2)$ & Age, BMI, hypertension, and diabetes mellitus. \\
\hline Soliman PT (2006)[31] & $0.089 \pm 0.006 / 0.148 \pm 0.068$ & ELISA & T1 vs. T3 & $O R$ & $10.5(4.18,26.35)$ & Age, BMI, hypertension, diabetes. \\
\hline Dal Maso L(2004) [32] & $11.4(6.5-17.1) / 16.0(8.4-22.5)$ & RIA & T3 vs. T1 & $\mathrm{OR}$ & $0.42(0.19,0.94)$ & Age, education, parity, smoking status, BMI, and HRT. \\
\hline Petridou E (2003)[21] & $13.5 \pm 5.3$ & RIA & $\begin{array}{l}1 \text { quintile } \\
\text { increase }\end{array}$ & OR & $0.74(0.56,0.97)$ & $\begin{array}{l}\text { Age, education, BMI, parity, IGF-I, IGF-II, IGFBP-3, and } \\
\text { leptin. }\end{array}$ \\
\hline \multicolumn{7}{|l|}{ Nested case-control studies } \\
\hline Luhn P (2013)[25] & $12.2(6.8,22.9) / 14.8(7.5,25.9)$ & RIA & T3vsT1 & OR & $0.73(0.43,1.27)$ & $\begin{array}{l}\text { Age, BMI, current smoking status, family history of } \\
\text { breast or endometrial cancer, education level, parity, } \\
\text { diabetes, oral contraceptive use, estradiol. }\end{array}$ \\
\hline Dallal CM (2013)[26] & $14.3(6.7,26.0) / 14.6(11.0,30.6)$ & ELISA $^{\triangle}$ & T3 vs. T1 & OR & $1.31(0.55,3.12)$ & Age, BMI or estradiol and C-peptide \\
\hline Soliman PT(2011)[27] & $12.9 / 12.9$ & ELISA & T3 vs. T1 & OR & $0.98(0.57,1.68)$ & Age, BMI, parity, diabetes. \\
\hline Cust AE(2007)[28] & $8.4(8.0-8.9) 9.9(9.5-10.3)$ & ELISA & Q4 vs. Q1 & $\mathrm{RR}$ & $0.63(0.36,1.10)$ & $\begin{array}{l}\text { Age, BMI, C-peptide, IGFBP-1, IGFBP-2, SHBG, estrone, } \\
\text { free testosterone. }\end{array}$ \\
\hline
\end{tabular}

to gain more information. These two studies were omitted from meta-analysis. Both of them suggested an inverse association between blood adiponectin level and endometrial cancer risk (Tables 1 and 2).

\section{Meta-analysis Results of case-control studies}

We initially performed a meta-analysis of case-control studies. Six studies [21, 23, 24, $29,30,32$ ] (Tables 1 and 2) were included in the pooled analysis. As shown in Figure 2, the pooled OR was 0.50 (95\% CI: $0.39-0.64 ; P<0.001)$ for the highest versus the lowest category of adiponectin levels. No statistical heterogeneity was found. Sensitivity analyses showed that the result from one study had significantly affected the pooled OR (data not show). In this study [24], the lowest tertile of serum adiponectin had been linked to a much elevated risk of endometrial cancer (OR=10.80, 95\%CI: 2.76-42.24). Even after eliminating this study, the pooled results still showed an inverse relationship between serum adiponectin level and endometrial cancer risk (pooled OR=0.53, 95\% CI: 0.41-0.69; $P<0.001$ ). 


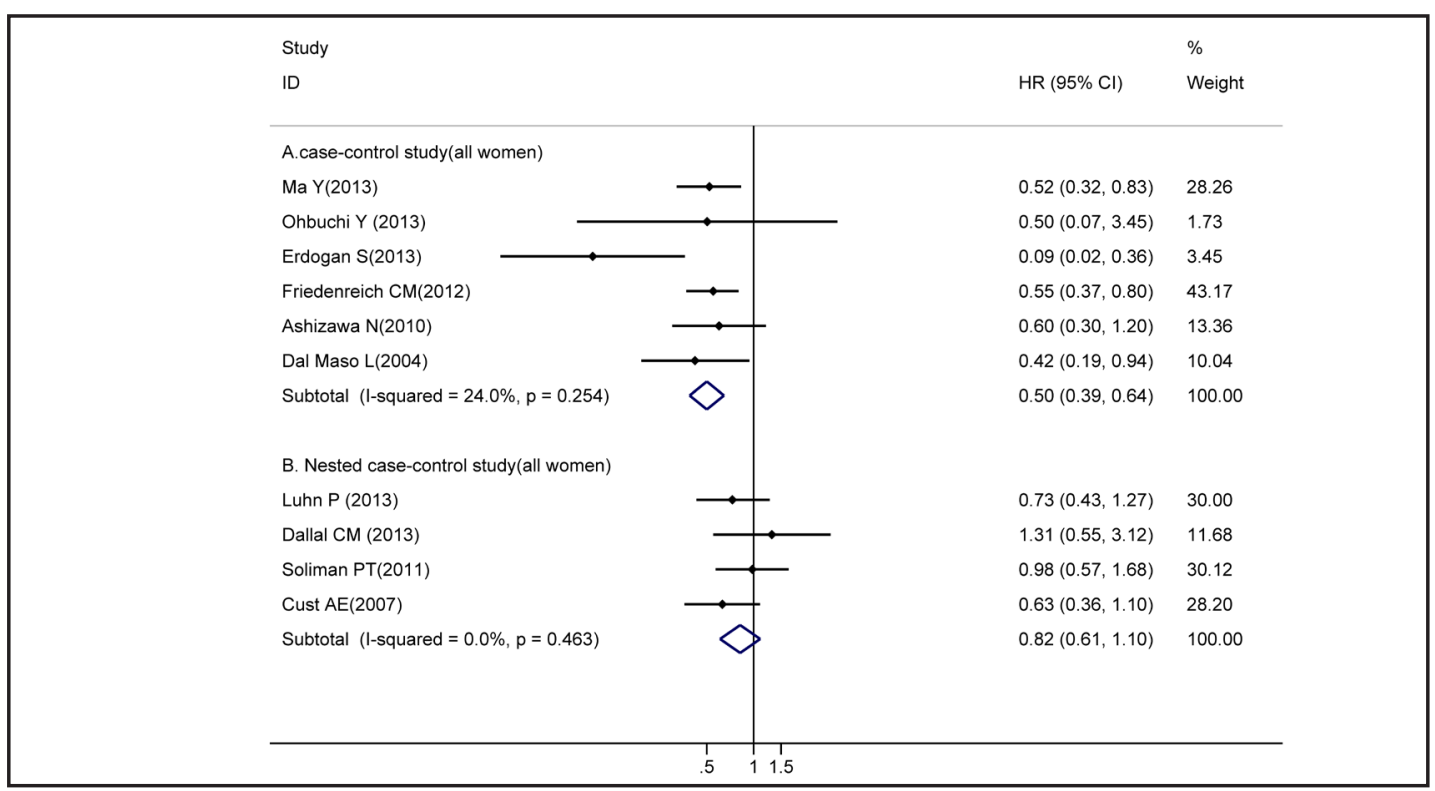

Fig. 2. Meta-analysis results of Case-control studies and Nested case-control studies.

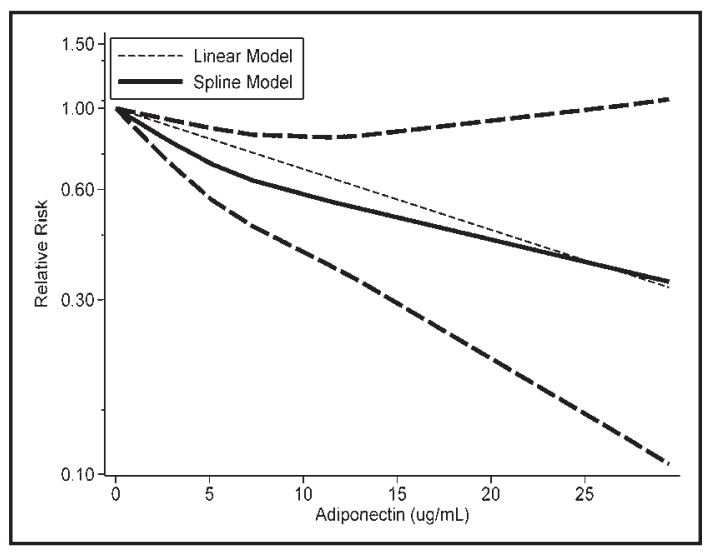

Fig. 3. Dose-response analysis of four case-control studies.

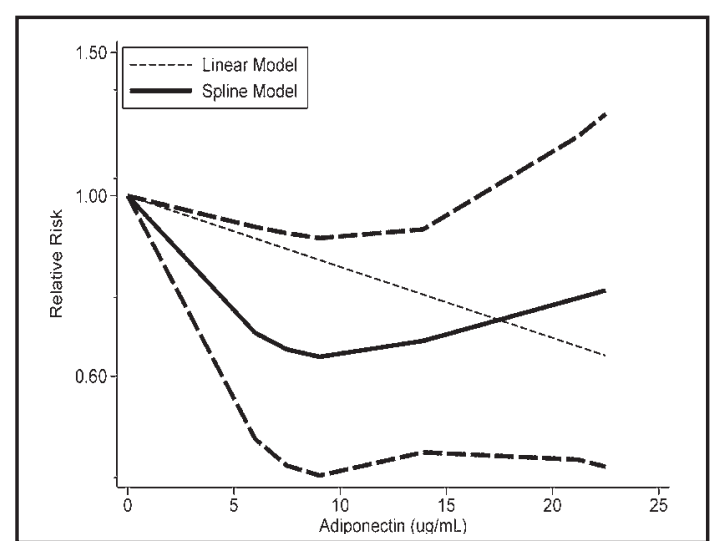

Fig. 4. Dose-response analysis of four nested case-control studie.

Four studies had data available for dose-response analysis. The combined OR for an increment of $10 \mu \mathrm{g} / \mathrm{ml}$ of adiponectin was 0.74 (95\% CI: 0.66-0.83; $\mathrm{P}<0.001$ )(Fig. 3). The results of subgroup analyses consistently showed inverse correlations between adiponectin levels and the risks of endometrial cancer development in most subgroups (Table 3).

\section{Meta-analysis of nested case-control studies}

We then performed a meta-analysis of four nested case-control studies [25-28] (Tables 1 and 2). The pooled OR from the nested case-control studies was not statistically significant (OR=0.82, 95\%CI: 0.61-1.10; $P=0.188$, Fig. 2 ) for the highest versus the lowest category of adiponectin levels. No statistical heterogeneity was found. No single study significantly affected the pooled OR in sensitivity analyses. Dose-response analysis showed that the combined OR of endometrial cancer for an increment of $10 \mu \mathrm{g} / \mathrm{ml}$ of adiponectin was 0.82 (95\% CI: 0.67, 1.00; P=0.055)(Fig. 4).

Further subgroup analysis in postmenopausal women revealed an increment of $10 \mu \mathrm{g} /$ $\mathrm{ml}$ of adiponectin was potentially associated with a reduced risk of endometrial cancer with marginal statistical significance (pooled OR=0.81, 95\%CI: 0.65-1.00, $\mathrm{P}=0.06$ ). Interestingly, 


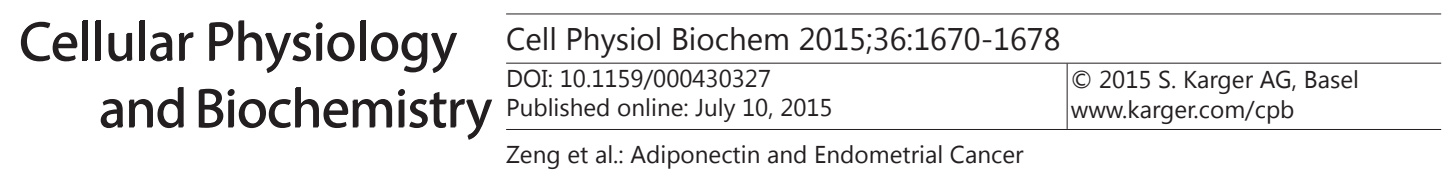

Table 3. Subgroup analysis of an increment of $10 \mu \mathrm{g} / \mathrm{ml}$ of serum adiponectin and endometrial cancer. * Others indicate all subjects or a part of subjects in a study were current HRT users. No study analyzed separately in former HRT users

\begin{tabular}{|c|c|c|c|c|c|}
\hline Subgroups & $\begin{array}{l}\text { Number of } \\
\text { study }\end{array}$ & $\begin{array}{l}\text { Pooled } \\
\text { OR(95\%CI) }\end{array}$ & $\begin{array}{l}\mathrm{P} \text { value for } \\
\text { assessment }\end{array}$ & $\begin{array}{l}\mathrm{P} \text { value for } \\
\text { heterogeneity }\end{array}$ & $\mathrm{I}^{2}$ \\
\hline \multicolumn{6}{|l|}{$\begin{array}{l}\text { Case control Studies } \\
\text { Study location }\end{array}$} \\
\hline Asian & 2 & $0.56(0.34,0.94)$ & 0.027 & 0.192 & 4.73 \\
\hline $\begin{array}{l}\text { Europe or North } \\
\text { America } \\
\text { Menopause status }\end{array}$ & 2 & $0.75(0.66,0.84)$ & $<0.001$ & 0.460 & 3.62 \\
\hline $\begin{array}{l}\text { Pre- or } \\
\text { perimenopause }\end{array}$ & 1 & $0.59(0.31,1.10)$ & 0.097 & --- & --- \\
\hline $\begin{array}{l}\text { Postmenopause } \\
\text { Current HRT use }\end{array}$ & 3 & $0.64(0.49,0.84)$ & 0.001 & 0.947 & 0.36 \\
\hline Others* & 3 & $0.74(0.66,0.83)$ & $<0.001$ & 0.160 & 9.24 \\
\hline $\begin{array}{l}\text { Non current user } \\
\text { Nested case control } \\
\text { Study location }\end{array}$ & $\begin{array}{l}1 \\
\text { dies }\end{array}$ & $0.67(0.39,1.16)$ & 0.152 & --- & --- \\
\hline Asian & 0 & -- & --- & --- & --- \\
\hline $\begin{array}{l}\text { Europe or North } \\
\text { America } \\
\text { Menopause status }\end{array}$ & 4 & $0.82(0.67,1.00)$ & 0.055 & 0.938 & 4.85 \\
\hline Pre-Peri menopause & 2 & $1.01(0.73,1.40)$ & 0.942 & 0.785 & 2.44 \\
\hline $\begin{array}{l}\text { Post menopause } \\
\text { Current HRT use }\end{array}$ & 4 & $0.81(0.65,1.00)$ & 0.060 & 0.891 & 2.94 \\
\hline Others* & 2 & $1.10(0.77,1.57)$ & 0.602 & 0.522 & 2.25 \\
\hline Non current user & 3 & $0.62(0.44,0.86)$ & 0.004 & 0.935 & 1.3 \\
\hline
\end{tabular}

Table 4. Quality analysis of included studies

\begin{tabular}{|c|c|c|c|c|c|c|c|c|}
\hline \multirow[t]{2}{*}{ Study ID } & \multicolumn{4}{|c|}{ Selection } & \multirow{2}{*}{$\begin{array}{c}\text { Comparability } \\
\text { Comparabitlity of } \\
\text { cases and controls on } \\
\text { the basis of the design } \\
\text { or analyisis }\end{array}$} & \multirow{2}{*}{\multicolumn{2}{|c|}{$\begin{array}{cc} & \text { Exposure } \\
\text { Assertainment } & \text { Same methods } \\
\text { of exposure } & \text { assertainment } \\
& \text { for case and } \\
\text { controls }\end{array}$}} & \multirow[b]{2}{*}{$\begin{array}{c}\text { Non-response } \\
\text { rate }\end{array}$} \\
\hline & $\begin{array}{l}\text { Is the case } \\
\text { definition } \\
\text { adequated }\end{array}$ & $\begin{array}{c}\text { Representative } \\
\text { of the cases }\end{array}$ & $\begin{array}{l}\text { Selection } \\
\text { of controls }\end{array}$ & $\begin{array}{l}\text { Definition } \\
\text { of controls }\end{array}$ & & & & \\
\hline \multicolumn{9}{|l|}{ Case control studies } \\
\hline Ma Y(2013)[22] & * & * & * & * & * & * & * & * \\
\hline Ohbuchi Y [2013][23] & $*$ & * & --- & * & * & * & $*$ & --- \\
\hline Erdogan S (2013)[24] & $*$ & $*$ & $\cdots$ & $\cdots$ & * & * & $*$ & 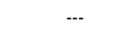 \\
\hline FriedenreichCM(2012)[29] & * & * & $*$ & $*$ & * & * & * & $*$ \\
\hline Ashizawa N.(2010)[30] & * & * & $\cdots$ & -.. & * & * & $*$ & -.- \\
\hline Soliman PT (2006)[31] & * & * & $\cdots$ & $*$ & $\cdots$ & * & * & $\ldots$ \\
\hline Dal Maso L(2004) [32] & * & * & -.. & * & $*$ & * & $*$ & $*$ \\
\hline Petridou E (2003)[21] & * & * & $\cdots$ & $*$ & * & * & $*$ & -.- \\
\hline \multicolumn{9}{|l|}{ Nested case-control studies } \\
\hline Luhn P (2013)[25] & * & * & * & * & $* *$ & $* *$ & * & * \\
\hline Dallal CM (2013)[26] & * & * & * & * & $* *$ & $* *$ & * & * \\
\hline Soliman PT(2011)[27] & * & * & * & * & * & * & * & * \\
\hline Cust AE(2007)[28] & * & * & * & * & ** & $* *$ & * & * \\
\hline
\end{tabular}

in postmenopausal women who were not currently treated with hormone replacement therapy, the pooled OR reached statistical significance (OR=0.62, 95\%CI: 0.44-0.86, $\mathrm{P}=0.004)$. No such association was observed in premenopausal women (Table 3).

\section{Publication Bias}

No publication biases were found in meta-analyses of both case-control studies and nested case-control studies.

\section{Discussion}

This is the first systematic meta-analysis of currently available clinical studies with respect to adiponectin and endometrial cancer. The reduction of blood concentrations of adiponectin, the most abundant circulating adipokine, has been postulated in a series of studies as a potential mechanism in linking obesity and elevated risk of endometrial cancer 


\section{Cellular Physiology Cell Physiol Biochem 2015;36:1670-1678

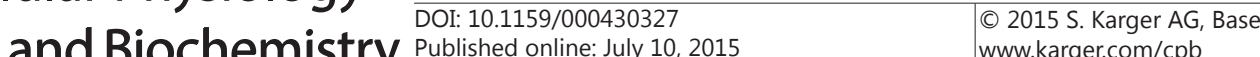

[36]. Adiponectin can suppress cellular growth through AMPK-mediated or non-AMPKmediated modulation of mTOR-S6K1, PI3K-AKT, JUN-STAT3, MAPK signaling pathways in a variety of cancer cells [7-15] including endometrial cancer cells [37]. Our meta-analysis of currently available case-control studies showed that high serum adiponectin concentration was inversely related to low risk of endometrial cancer. In nested case-control studies, however, this association existed only in postmenopausal women who were not under current hormone replacement therapy. There were only six case-control studies and four nested case-control studies presented available data for pooled analysis, the numbers were fewer when it comes to subgroup analyses, so such results should be explained with caution.

Recent studies have suggested that high molecular-weight (HMW) adiponectin is the bioactive form of the protein [6]. To date, there has only been two studies that analyzed the association between higher level of HMW adiponectin and endometrial cancer, both of which had null results $(0.87,95 \% \mathrm{CI} 0.37-2.09$ and $3.45,95 \% \mathrm{CI} \quad 0.52-22.73) \quad$ [23, 26]. One study [23] also analyzed this association between middle molecular weight (MMW) and endometrial cancer, and suggested low MMW was the only independent risk factor for endometrial cancer $(\mathrm{OR}=4.892,95 \% \mathrm{CI} 1.252-19.114)$. The apparent contradicting effects of different isoforms of adiponectin on the risk of endometrial cancer need to be further investigated.

Leptin is another hormone that is elevated in obese women and secreted from adipocytes. The leptin/adiponectin ratio could, therefore, theoretically be more powerful in the prediction of endometrial cancer. Two nested case-controls and two case-control studies analyzed the involvement of leptin/adiponectin ratio and endometrial cancer risk $[25,26,29$, $30]$. However, the pooled analysis of these studies produced a null result(data not shown), which might be due to the small number of studies and the small sample size available for analysis. Additional prospective studies are needed to further investigate these issues.

The major limitation of this meta-analysis was that the number of currently available studies, particularly the prospective studies, was still limited. Such limitation was even more obvious in subgroup analysis, e.g. only one case-control study provided data about postmenopausal women without current HRT, and no sufficient studies for graphical description of results of dose responsive analysis. This limitation certainly weakened the results of this analysis. The second one was that few studies presented data about former use of HRT. One of the important results of the present study was that the association between adiponectin and endometrial cancer was obvious in postmenopausal women who were currently not under HRT therapy. This results suggested estrogen activity in HRT still play the dominant role over the effect of adiponectin-deficiency on endometrial cancer development. Future studies should lay emphasis on former users of HRT, which could shed more light on the effects of exogenous estrogen on the link of adiponectin to endometrial cancer. The third limitation is the potential limitation of publication bias. Although no evidence of publication bias was found in the meta-analysis, studies with null results might have existed. To minimize this risk, we searched the ISI web of knowledge database and qualified reviews for potential unpublished studies with null results, with no such studies were found.

\section{Conclusion}

The existing evidence suggests an inverse relationship between blood adiponectin levels and endometrial cancer risk, particularly in postmenopausal women without current hormone replacement therapy. Additional prospective studies with large sample sizes are needed to fully support such potential linkage.

\section{Disclosure Statement}

The authors have no conflicts of interest to declare. 


\section{Cellular Physiology Cell Physiol Biochem 2015;36:1670-1678 \begin{tabular}{l|l|l}
\hline DOI: 10.1159/000430327 & (C) 2015 S. Karger AG, Basel
\end{tabular} www.karger.com/cpb \\ Zeng et al.: Adiponectin and Endometrial Cancer}

\section{Acknowledgement}

This study was supported by the grants from the National Key Basic Research Program (2013CB945202 to FL and AZ), the National Nature Science Foundation of China (81170780, 81372798, 81100572 to AZ, FL, and TC, respectively), the Ph.D. Program Foundation of Ministry of Education of China (20113234110005 to AZ), as well as a grant for the Returned Overseas Scholars of the first affiliated hospital of Nanjing Medical University (to FL).

\section{References}

1 Akhmedkhanov A, Zeleniuch-Jacquotte A, Toniolo P: Role of exogenous and endogenous hormones in endometrial cancer. Ann N Y Acad Sci 2001;943:296-315.

2 Renehan AG, Frystyk J, Flyvbjerg A: Obesity and cancer risk: The role of the insulin-igf axis. Trends Endocrinol Metab 2006;17:328-336.

3 Barb D, Williams CJ, Neuwirth AK, Mantzoros CS: Adiponectin in relation to malignancies: A review of existing basic research and clinical evidence. Am J Clin Nutr 2007;86:s858-866.

4 Cottam DR, Mattar SG, Barinas-Mitchell E, Eid G, Kuller L, Kelley DE, Schauer PR: The chronic inflammatory hypothesis for the morbidity associated with morbid obesity: Implications and effects of weight loss. Obes Surg 2004;14:589-600.

5 Wang PP, He XY, Wang R, Wang Z, Wang YG: High leptin level is an independent risk factor of endometrial cancer: A meta-analysis. Cell Physiol Biochem 2014;34:1477-1484.

6 Kadowaki T, Yamauchi T: Adiponectin and adiponectin receptors. Endocr Rev 2005;26:439-451.

7 Nakayama S, Miyoshi Y, Ishihara H, Noguchi S: Growth-inhibitory effect of adiponectin via adiponectin receptor 1 on human breast cancer cells through inhibition of s-phase entry without inducing apoptosis. Breast Cancer Res Treat 2008;112:405-410.

8 Taliaferro-Smith L, Nagalingam A, Zhong D, Zhou W, Saxena NK, Sharma D: Lkb1 is required for adiponectin-mediated modulation of ampk-s6k axis and inhibition of migration and invasion of breast cancer cells. Oncogene 2009;28:2621-2633.

9 Wang Y, Lam JB, Lam KS, Liu J, Lam MC, Hoo RL, Wu D, Cooper GJ, Xu A: Adiponectin modulates the glycogen synthase kinase-3beta/beta-catenin signaling pathway and attenuates mammary tumorigenesis of mda-mb-231 cells in nude mice. Cancer Res 2006;66:11462-11470.

10 Pfeiler GH, Buechler C, Neumeier M, Schaffler A, Schmitz G, Ortmann O, Treeck O: Adiponectin effects on human breast cancer cells are dependent on 17-beta estradiol. Oncol Rep 2008;19:787-793.

11 Cong L, Gasser J, Zhao J, Yang B, Li F, Zhao AZ: Human adiponectin inhibits cell growth and induces apoptosis in human endometrial carcinoma cells, hec-1-a and rl95 2. Endocr Relat Cancer 2007;14:713720.

12 Mistry T, Digby JE, Desai KM, Randeva HS: Leptin and adiponectin interact in the regulation of prostate cancer cell growth via modulation of p53 and bcl-2 expression. BJU Int 2008;101:1317-1322.

13 Bub JD, Miyazaki T, Iwamoto Y: Adiponectin as a growth inhibitor in prostate cancer cells. Biochem Biophys Res Commun 2006;340:1158-1166.

14 Ishikawa M, Kitayama J, Yamauchi T, Kadowaki T, Maki T, Miyato H, Yamashita H, Nagawa H: Adiponectin inhibits the growth and peritoneal metastasis of gastric cancer through its specific membrane receptors adipor1 and adipor2. Cancer Sci 2007;98:1120-1127.

15 Sugiyama M, Takahashi H, Hosono K, Endo H, Kato S, Yoneda K, Nozaki Y, Fujita K, Yoneda M, Wada K, Nakagama H, Nakajima A: Adiponectin inhibits colorectal cancer cell growth through the ampk/mtor pathway. Int J Oncol 2009;34:339-344.

16 Kelesidis I, Kelesidis T, Mantzoros CS: Adiponectin and cancer: A systematic review. Br J Cancer 2006;94:1221-1225.

17 Jiang HL, Xu D, Yu H, Ma X, Lin GF, Ma DY, Jin JZ: Dax-1 inhibits hepatocellular carcinoma proliferation by inhibiting beta-catenin transcriptional activity. Cell Physiol Biochem 2014;34:734-742.

18 Guo Y, Liao Y, Jia C, Ren J, Wang J, Li T: Microrna-182 promotes tumor cell growth by targeting transcription elongation factor a-like 7 in endometrial carcinoma. Cell Physiol Biochem 2013;32:581-590. 


\section{Cellular Physiology Cell Physiol Biochem 2015;36:1670-1678 \begin{tabular}{l|l|l}
\hline DOI: 10.1159/000430327 & C 2015 S. Karger AG, Basel
\end{tabular} www.karger.com/cpb \\ Zeng et al.: Adiponectin and Endometrial Cancer}

19 Perrier S, Jarde T: Adiponectin, an anti-carcinogenic hormone? A systematic review on breast, colorectal, liver and prostate cancer. Curr Med Chem 2012;19:5501-5512.

20 An W, Bai Y, Deng SX, Gao J, Ben QW, Cai QC, Zhang HG, Li ZS: Adiponectin levels in patients with colorectal cancer and adenoma: A meta-analysis. Eur J Cancer Prev 2012;21:126-133.

21 Petridou E, Mantzoros C, Dessypris N, Koukoulomatis P, Addy C, Voulgaris Z, Chrousos G, Trichopoulos D: Plasma adiponectin concentrations in relation to endometrial cancer: A case-control study in greece. J Clin Endocrinol Metab 2003;88:993-997.

22 Ma Y, Liu Z, Zhang Y, Lu B: Serum leptin, adiponectin and endometrial cancer risk in chinese women. J Gynecol Oncol 2013;24:336-341.

23 Ohbuchi Y, Suzuki Y, Hatakeyama I, Nakao Y, Fujito A, Iwasaka T, Isaka K: A lower serum level of middlemolecular-weight adiponectin is a risk factor for endometrial cancer. Int J Clin Oncol 2014; 19:667-673

24 Erdogan S, Sezer S, Baser E, Gun-Eryilmaz O, Gungor T, Uysal S, Yilmaz FM: Evaluating vaspin and adiponectin in postmenopausal women with endometrial cancer. Endocr Relat Cancer 2013;20:669-675.

25 Luhn P, Dallal CM, Weiss J, Black A, Huang WY, Lacey JV, Hayes RB, Stanczyk FZ, Wentzensen N, Brinton LA: Circulating adipokine levels and endometrial cancer risk in the prostate, lung, colorectal and ovarian cancer screening trial. Cancer Epidemiol Biomarkers Prev 2013; 22:1304-1312.

26 Dallal CM, Brinton LA, Bauer DC, Buist DS, Cauley JA, Hue TF, Lacroix A, Tice JA, Chia VM, Falk R, Pfeiffer R, Pollak M, Veenstra TD, Xu X, Lacey JV, Jr., Group BFR: Obesity-related hormones and endometrial cancer among postmenopausal women: A nested case-control study within the b fit cohort. Endocr Relat Cancer 2013;20:151-160.

27 Soliman PT, Cui X, Zhang Q, Hankinson SE, Lu KH: Circulating adiponectin levels and risk of endometrial cancer: The prospective nurses' health study. Am J Obstet Gynecol 2011;204:167 e161-165.

28 Cust AE, Kaaks R, Friedenreich C, Bonnet F, Laville M, Lukanova A, Rinaldi S, Dossus L, Slimani N, Lundin E, Tjonneland A, Olsen A, Overvad K, Clavel-Chapelon F, Mesrine S, Joulin V, Linseisen J, Rohrmann S, Pischon T, Boeing H, Trichopoulos D, Trichopoulou A, Benetou V, Palli D, Berrino F, Tumino R, Sacerdote C, Mattiello A, Quiros JR, Mendez MA, Sanchez MJ, Larranaga N, Tormo MJ, Ardanaz E, Bueno-de-Mesquita HB, Peeters PH, van Gils CH, Khaw KT, Bingham S, Allen N, Key T, Jenab M, Riboli E: Plasma adiponectin levels and endometrial cancer risk in pre- and postmenopausal women. J Clin Endocrinol Metab 2007;92:255-263.

29 Friedenreich CM, Langley AR, Speidel TP, Lau DC, Courneya KS, Csizmadi I, Magliocco AM, Yasui Y, Cook LS: Case-control study of markers of insulin resistance and endometrial cancer risk. Endocr Relat Cancer 2012;19:785-792.

30 Ashizawa N, Yahata T, Quan J, Adachi S, Yoshihara K, Tanaka K: Serum leptin-adiponectin ratio and endometrial cancer risk in postmenopausal female subjects. Gynecol oncol 2010;119:65-69.

31 Soliman PT, Wu D, Tortolero-Luna G: Association between adiponectin, insulin resistance, and endometrial cancer. Cancer 2006;107:2314-2314.

32 Dal Maso L, Augustin LS, Karalis A, Talamini R, Franceschi S, Trichopoulos D, Mantzoros CS, La Vecchia C: Circulating adiponectin and endometrial cancer risk. J Clin Endocrinol Metab 2004;89:1160-1163.

33 Wells GA, Shea B, O'Connell D, Peterson J, Welch V, Losos M, Tugwell P: The newcastle-ottawa scale (nos) for assessing the quality of nonrandomised studies in metaanalyses. Available:http://www.ohri.ca/ programs/clinical_epidemiology/oxford.asp. Accessed 2 June 2015

34 Greenland S, Longnecker MP: Methods for trend estimation from summarized dose-response data, with applications to meta-analysis. Am J Epidemiol 1992;135:1301-1309.

35 Orsini N, Li R, Wolk A, Khudyakov P, Spiegelman D: Meta-analysis for linear and nonlinear dose-response relations: Examples, an evaluation of approximations, and software. Am J Epidemiol 2012;175:66-73.

36 Renehan AG, Tyson M, Egger M, Heller RF, Zwahlen M: Body-mass index and incidence of cancer: A systematic review and meta-analysis of prospective observational studies. Lancet 2008;371:569-578.

37 Izadi V, Farabad E, Azadbakht L: Serum adiponectin level and different kinds of cancer: A review of recent evidence. ISRN oncol 2012;2012:982769. 